\title{
In-silico TOXICITY PREDICTION OF BIOACTIVE COMPOUNDS OF Vernonia amygdalina DELILE. AND DIGOXIN
}

\author{
R.A. Syahputra ${ }^{1}$, U.Harahap ${ }^{1, *}$, A. Dalimunthe ${ }^{1}$, P. Nasution $^{2}$, G. Haro ${ }^{3}$, \\ Widodo $^{4}$, D.H. Utomo ${ }^{4}$, and D. Satria ${ }^{2}$ \\ ${ }^{1}$ Department of Pharmacology, Faculty of Pharmacy, Universitas Sumatera Utara, \\ Medan-20155, Indonesia \\ ${ }^{2}$ Department of Pharmaceutical Biology, Faculty of Pharmacy, Universitas Sumatera Utara, \\ Medan-20155, Indonesia \\ ${ }^{3}$ Department of Pharmaceutical Chemistry, Faculty of Pharmacy, Universitas Sumatera Utara, \\ Medan-20155, Indonesia \\ ${ }^{4}$ Faculty of Mathematics and Natural Sciences, Universitas Brawijaya, Malang-65145,Indonesia. \\ *E-mail: urip@usu.ac.id
}

\begin{abstract}
Vernonia amygdalina Delile. is commonly found in a tropical area, it has an inotropic effect on the heart and has phytochemical constituents that are similar to digoxin such as vernonioside D and vernonioside A3. This study aimed to determine the prediction of toxicity level and value of the bond energy between digoxin, vernonioside D, and vernonioside A3 on the enzyme $\mathrm{Na}^{+} / \mathrm{K}^{+}$ATPase In silico method. Prediction of ADMET was determined by using the pkCSM website, Prediction of toxicity of chemical were determined by protox II website and docking analysis in this study was carried out using the AutoDock software with PDB code 4RET and visualization using polymol. The results showed that digoxin induces CYP3A4 receptors while vernonioside D and A3 did not induce CYP3A4 receptors. Prediction of $\mathrm{LD}_{50}$ was digoxin $5 \mathrm{mg} / \mathrm{kg}$ (fatal), while vernonioside $\mathrm{D}$ has a prediction of $\mathrm{LD}_{50}$ was $8000 \mathrm{mg} / \mathrm{kg}$ (non-toxic) and vernonioside A3 has a prediction of $\mathrm{LD}_{50}$ was $8000 \mathrm{mg} / \mathrm{kg}$ (non-toxic). Digoxin, vernonioside D and vernonioside A3 inhibited hERG II. The binding energy value of $\mathrm{Na}^{+} / \mathrm{K}^{+} \mathrm{ATPase}$ to digoxin was obtained value $-12 \mathrm{Kcal} / \mathrm{mol}$, vernonioside $\mathrm{D}$ was obtained a value of $-9 \mathrm{Kcal} / \mathrm{mol}$ while vernonioside A3 was obtained a value of $-9.4 \mathrm{Kcal} / \mathrm{mol}$. Based on the research, it can be concluded that vernonioside $\mathrm{D}$ and vernonioside A3 has a lower toxicity level compared to digoxin, while the affinity of digoxin for $\mathrm{Na}^{+} / \mathrm{K}^{+} \mathrm{ATPase}$ has higher compared to Vernonioside D and vernonioside A3.
\end{abstract}

Keywords: Toxicity, In-silico, Digoxin, Vernonioside D, Vernonioside A3.

(C) RASĀYAN. All rights reserved

\section{INTRODUCTION}

Vernonia amygdalina Delile. is a plant that is commonly found in Africa and also in tropical regions such as Indonesia, which is a family of Asteraceae, this plant has been widely used traditionally for treatment, and it is known that Vernonia amygdalina extract can treat chimpanzees affected by malaria ${ }^{1}$. Vernonia amygdalina has many pharmacological effects including antidiabetic, nephroprotective, antioxidant, antihyperlipidemic, immunological effects, anthelmintic, anti-obesity, hepatoprotection, and antiinflammatory. based on the previous research reported that ethanol extract of Vernonia amygdalina is also known as a higher inotropic compared to digoxin in rats in the heart ${ }^{2-10}$. African leaves contain compounds such as saponins, flavonoids, lactone sesquiterpenes, and steroid glycosides such as vernonioside b1, vernonioside a2, vernonioside a3, vernonioside b1, vernonioside d, vernonioside e and vernonioside b2 and have steroid saponin vernonioside a3, vernonioside a3, vernonioside b1, vernonioside d, vernonioside e and vernonioside a2, vernonioside a2, vernonioside a3, vernonioside b1, vernonioside $\mathrm{d}$, vernonioside e and vernonioside b2 and have steroid vernonioside, vernonioside a3, vernonioside b1, vernonioside d, vernonioside e 2 and vernonioside b2, vernonioside a2, vernonioside a3,

Rasayan J. Chem., 13(2), 1220-1224(2020)

http://dx.doi.org/10.31788/RJC.2020.1325638 
vernonioside $b 1$, vernonioside $d$. vernoniamyoside $a$, vernoniamyoside $b$, vernoniamyoside $c$, vernoniamyoside $d$, and vernoamyoside $d$ this structurly similar to digoxin ${ }^{11-15}$. Digoxin is a cardiac glycoside isolated from the Digitalis purpurea foxglove plant. Cardiac glycosides are used as a treatment for positive inotropic congestive heart failure, atrial fibrillation, and diuretic. Lately known have anticancer activity ${ }^{16-18}$. This aimed of this study to determine the prediction of toxicity level and value of the bond energy between digoxin, vernonioside $\mathrm{D}$, vernonioside A3 on the enzyme $\mathrm{Na}^{+} / \mathrm{K}^{+} \mathrm{ATPase}$ with In silico method.

\section{Software}

\section{EXPERIMENTAL}

Asus core i3 64 bite, Chemdraw, pKCSM online tool, Protox online tool, AutoDock, dan Polymol.

\section{Target and Template Selection}

PDB code of $\mathrm{Na}^{+} / \mathrm{K}^{+}$ATPase: 4RET that was taken from Protein data bank (https://www.rcsb.org/) and smiles data of digoxin and vernonioside D and A3 were taken from Pubchem compound (https: //PubChem.ncbi.nlm.nih.gov/).

\section{Computational Assay : Prediction of ADMET}

In silico ADMET (Absorption, Distribution, Metabolism, Excretion, Toxicity) using the SMILES series for Digoxin, Vernoniosde D, and Vernonioside A3 isolates from African leaves. The properties of Digoxin and Vernonioside isolates were determined using the pkCSM website (http://biosig.unimelb.edu.au/pkcsm/) and the Prediction of the Toxicity of Chemical was determined using Protox II website (http://tox.charite.de/protox_II/). Prediction of Toxicity Class of chemical divided into: Class 1: Fatal (LD50 $\leq 5)$, Class 2: Fatal $(5<\operatorname{LD} 50 \leq 50)$, Class 3: Toxic $(50<\operatorname{LD} 50 \leq 300)$, Class 4: Harmful $(300<$ LD50 $\leq 2000)$, Class 5: Maybe harmful $(2000<$ LD50 $\leq 5000)$, Class 6: non-toxic (LD50 $>$ $5000)$.

\section{In-silico Analysis of Inhibition $\mathrm{Na}^{+} / \mathrm{K}^{+}$-ATPase}

Docking in this study was carried out using AutoDock software with PDB code (4RET). The affinity of the ligand with the target protein is shown in the resulting score. The lower the score the more stable the ligand-receptor bond and visualized in $2 \mathrm{D}$ the bond using polymol.

\section{RESULTS AND DISCUSSION}

\section{Prediction ADMET of Digoxin, Vernonioside D, Vernonioside A3 (pkCSM)}

From the computational results obtained pharmacokinetic data of digoxin, vernonioside $\mathrm{D}$, and vernonioside A3 below in Table-1.

Table-1: Data of pkCSM of Digoxin, Vernonioside D, and Vernonioside A3

\begin{tabular}{c|c|c|c|c|c}
\hline Property & Model Name & $\begin{array}{c}\text { Predicted Value of } \\
\text { Digoxin }\end{array}$ & $\begin{array}{c}\text { Predicted Value of } \\
\text { Vernonioside D }\end{array}$ & $\begin{array}{c}\text { Predicted Value of } \\
\text { Vernonioside A3 }\end{array}$ & Unit \\
\hline Absorption & $\begin{array}{c}\text { Water } \\
\text { Solubility }\end{array}$ & -4.096 & -3.215 & -3.29 & $\begin{array}{c}\text { Numeric }(\log \\
\mathrm{mol} / \mathrm{L})\end{array}$ \\
\hline Distribution & VDss (human) & 0.199 & 0.225 & 0.088 & $\begin{array}{c}\text { Numeric }(\log \\
\mathrm{L} / \mathrm{kg})\end{array}$ \\
\hline Metabolism & $\begin{array}{c}\text { CYP3A4 } \\
\text { Substrate }\end{array}$ & Yes & No & No & $\begin{array}{c}\text { Categorical } \\
\text { (Yes/No) }\end{array}$ \\
\hline Excretion & $\begin{array}{c}\text { Total } \\
\text { Clearance }\end{array}$ & 0.479 & 0.317 & 0.335 & $\begin{array}{c}\text { Numeric }(\log \\
\mathrm{ml} / \mathrm{min} / \mathrm{kg})\end{array}$ \\
\hline Toxicity & $\begin{array}{c}\text { hERG II } \\
\text { Inhibitor }\end{array}$ & Yes & Yes & Yes & $\begin{array}{c}\text { Categorical } \\
\text { (Yes/No) }\end{array}$ \\
\hline
\end{tabular}

Table-1 showed that digoxin induces CYP3A4 receptors which can affect other drugs that are inhibiting the CYP3A4 enzyme and can cause toxicity such as Amiodarone, Atazanapir, Chloramphenicol, 
RASĀYAN J. Chem.

Vol. 13 | No. 2 |1220-1224| April - June | 2020

Diltiazem, and others. Digoxin inhibits hERGII which is a gene that encodes the $\mathrm{Na}^{+} / \mathrm{K}^{+}$ATPase protein sub-unit of alpha in the Potassium channel, the inhibitory effect of this potassium channel is needed to inhibit the exchange of $\mathrm{Na}$ which causes increased concentration of $\mathrm{Na}$ in the cell and is exchanged with $\mathrm{Ca}$ through the $\mathrm{Na} / \mathrm{Ca}$ Exchanger channel which causes increased concentration $\mathrm{Ca}$ in cells and the inotropic activity to increase ${ }^{19-20}$. Vernonioside D and vernonioside A3 did not induce CYP3A4 enzymes, this could indicate vernonioside D and A3 are safer to use compared to digoxin. Vernonioside D and vernonioside A3 inhibit hERG II which has the same mechanism as digoxin to produce an inotropic effect ${ }^{21}$.

\section{Prediction Rules of Five Lipinski}

Table-2 showed that digoxin has a molecular weight of digoxin was $780.94 \mathrm{~g} / \mathrm{mol}$ greater than vernonioside D was $664.78 \mathrm{~g} / \mathrm{mol}$ and vernonioside A3 was $678.86 \mathrm{~g} / \mathrm{mol}$ so that all three compounds did not meet the Lipinski requirements, $\log \mathrm{P}$ all compounds meet the Lipinski requirements, the number of acceptors for digoxin was 14 is greater than that of vernonioside $\mathrm{D}$ was 12 and vernonioside A3 was 11 so that the three compounds did not meet Lipinski's requirements, and the number of donors for digoxin was 6 , vernonioside was D 7, and vernonioside A3 was 6 , the three compounds also did not meet Lipinski's requirements. Thus the three compounds are difficult to absorb and have low permeability, but when data is compared to the three compounds the vernonioside compound is easier to absorb and higher permeability when compared to digoxin based on the results of the rules of five Lipinski ${ }^{22}$.

Table-2: Prediction of Rules of Five

\begin{tabular}{c|c|c|c|c|c}
\hline No. & Parameter & Requierment & Digoxin & Vernonioside D & Vernonioside A3 \\
\hline 1. & Moleculer weight & $<500$ & 780.94 & 664.78 & 678.86 \\
\hline 2. & LogP & $\leq 5$ & 2.21 & 0.48 & 2.54 \\
\hline 3. & Acceptors & $\leq 10$ & 14 & 12 & 11 \\
\hline 4. & Donors & $\leq 5$ & 6 & 7 & 6 \\
\hline
\end{tabular}

Toxicity Prediction of Digoxin, Vernonioside D, Vernonioside A3

Table-3 showed that digoxin has fatal toxicity with $\mathrm{LD}_{50}$ was $5 \mathrm{mg} / \mathrm{kg}$ body weight. The oral dose of digoxin is only $0.25 \mathrm{mg} / \mathrm{kgBW}$ so the use of digoxin is very limited and has a narrow therapeutic index ${ }^{23}$. The vernonioside $D$ and vernonioside $A 3$ compounds have a prediction of $L_{50}$ was $8000 \mathrm{mg} / \mathrm{kg}$ with the non-toxic category when compared with digoxin is categorized as fatal, vernonioside $\mathrm{D}$ and vernonioside A3 are far safer to use based on the data.

Table-3: Toxicity Prediction of Digoxin, Vernonioside D, Vernonioside A3

\begin{tabular}{c|c|c|c|c}
\hline No. & Parameter & Digoxin & Vernonioside D & Vernonioside A3 \\
\hline 1. & Predicted LD 50 & $5 \mathrm{mg} / \mathrm{kg}$ & $8000 \mathrm{mg} / \mathrm{kg}$ & $8000 \mathrm{mg} / \mathrm{kg}$ \\
\hline 2. & Predicted toxicity class & Class 1 & Class 6 & Class 6 \\
\hline 3. & Average similarity & $100 \%$ & $78,94 \%$ & $76,68 \%$ \\
\hline 4. & Prediction accuracy & $100 \%$ & $69,26 \%$ & $69,26 \%$ \\
\hline
\end{tabular}

\section{In silico Analysis of Inhibition $\mathrm{Na}^{+} / \mathrm{K}^{+}$-ATPase}

Table-4 showed that digoxin has an affinity binding value of $-12(\mathrm{Kcal} / \mathrm{mol})$ while vernonioside $\mathrm{D}$ was -9 ( Kcal $/ \mathrm{mol})$ and vernonioside A 3 was $-9.4(\mathrm{Kcal} / \mathrm{mol})$. According to previous research, the bond energy value of bonding results In silico is the affinity of the bond between the test compound (ligand) and the bond bag. The lower the bond energy value of the bonding results In silico, the stronger the interaction between the test compound molecules (ligands) and the bond sac molecules. Digoxin has a stronger affinity for $\mathrm{Na}^{+} / \mathrm{K}^{+}$ATPase compared to vernonioside D and vernonioside A3.

Table-4: Binding Affinity of Digoxin, Vernonioside A3, Vernonioside D

\begin{tabular}{c|c|c}
\hline No. & Ligand & Binding Affinity $(\mathrm{Kcal} / \mathrm{mol})$ \\
\hline 1. & Digoksin & -12 \\
\hline 2. & Vernonioside A3 & $-9,4$ \\
\hline 3. & Vernoniosides D & -9 \\
\hline
\end{tabular}


2D Amino Acid of 4RET bind on Digoxin and Vernonioside A3

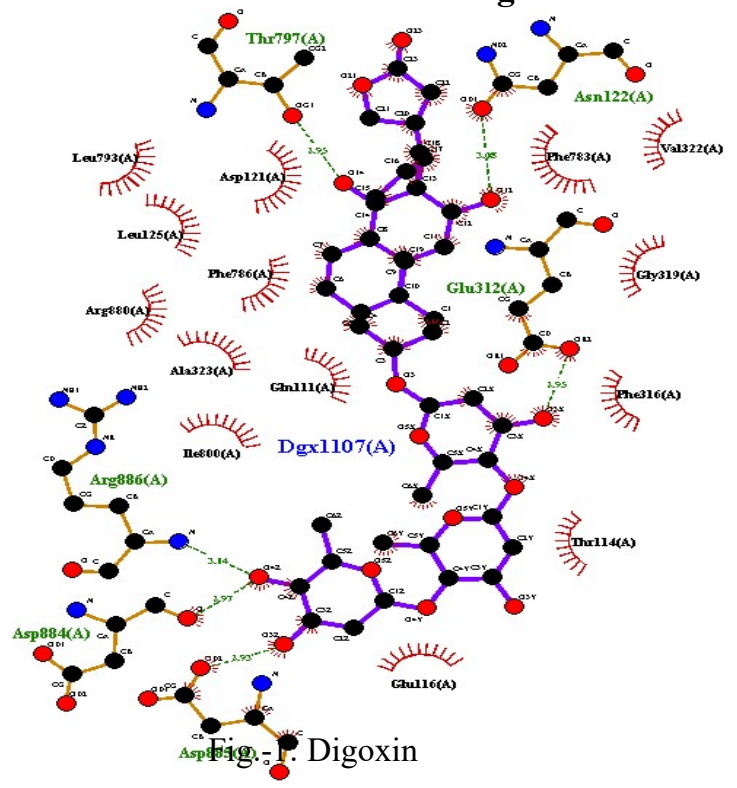

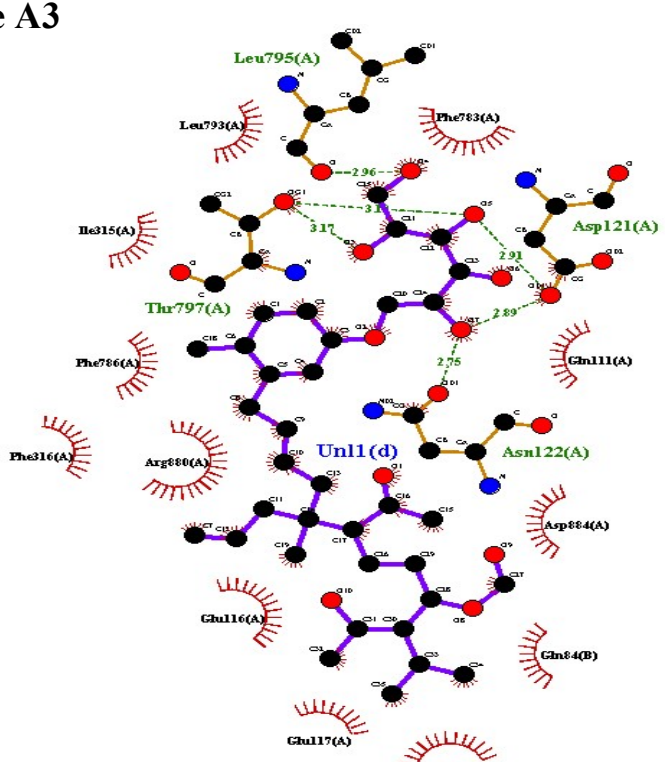

Fig.-2: Vernoniơsite A3

\section{Amino Acids Bind to 4RET on Digoxin and Vernonioside A3}

The Table-5 showed the hydrogen bonds of digoxin compounds with 4RET amino acids in several 5 bonds namely with glu312, arg886, asp885, asn122 and asp884 whereas with A3 vernonioside compounds a total of 4 bonds namely leu795, asp121, asn122, and thr797. The abundance of hydrogen amino acid digoxin bonds with 4RET compounds causes the bond energy to be lower than that of vernonioside A3 which causes digoxin activity to be higher compared to vernonioside A3. Table-5 and Table-6 show that the amino acid Asn122 (asparagine 122) is an amino acid that is bound to both compounds and the bond is a hydrogen bond that causes both compounds to inhibit receptors by competitive inhibitors.

Table-5: The Same Amino Acids bind to 4RET on Digoxin and Vernonioside A3

\begin{tabular}{c|c|c}
\hline Asam amino & Digoxin & Vernonioside A3 \\
\hline Phe783 & Present & Present \\
\hline Phe316 & Present & Present \\
\hline Glu116 & Present & Present \\
\hline Arg880 & Present & Present \\
\hline Phe786 & Present & Present \\
\hline Leu793 & Present & Present \\
\hline Asn122 & Present & Present
\end{tabular}

Table-6: Hydrogen bind of Amino Acid of 4RET on Digoxin and Vernonioside A3

\begin{tabular}{c|c}
\hline Digoxin & Vernonioside A3 \\
\hline Glu312 & Leu795 \\
\hline Arg886 & Asp121 \\
\hline Asn122 & Asn122 \\
\hline Asp885 & Thr797 \\
\hline Asp884 & \\
\hline
\end{tabular}

\section{CONCLUSION}

Based on the research, it can be concluded that vernonioside D and vernonioside A3 have a lower toxicity level compared to digoxin, while the affinity of digoxin for $\mathrm{Na}^{+} / \mathrm{K}^{+}$ATPase are higher compared to Vernonioside D and Vernonioside A3

\section{ACKNOWLEDGMENT}

The research was funded by the Universitas Sumatera Utara following the USU TALENTA Research (Penelitian Kerja Sama Dalam Negeri 2019) implementation contract for the fiscal year 2019 Number: 
RASĀYAN J. Chem.

Vol. 13 | No. 2 |1220-1224| April - June | 2020

4167 / UN.5.1.R / PPM / 2019 dated April 12019 and Hibah PMDSU 2019. Each author has a different contribution, for study conception and design was done by Rony abdi Syahputra and Urip harahap. Acquisition of data was done by Aminah dalimunthe, Ginda Haro, Pandapotan Nasution; Analysis and interpretation of data was done by Denny satria, Widodo, D. H. Utomo.

\section{REFERENCES}

1. H. Ohigashi, M. Jisaka, T. Takagi, H. Nozaki, T. Tada, M. A. Huffman, T. Nishida, M. Kaji, and K. Koshimazu, Agricultural and Biological Chemistry, 55, 4(1991), DOI:10.1271/bbb1961.55.1201

2. P. Erasto, D. S. Grierson, and A. J. Afolayan, Food Chemistry, 104, 2(2007), DOI:10.1016/j.foodchem.2006.12.013

3. O. A. Adaramoye, Vascular Health and Risk Management, 4, 1(2008), DOI:10.2147/vhrm.2008.04.01.235

4. P. Ebong and I. Atangwho, Agriculture and Biology Journal of North America, 2, 7(2011), DOI:10.5251/abjna.2011.2.7.1087.1095

5. A. A. Adedapo, O. O. Falayi, and A. A. Oyagbemi, Journal of Basic and Clinical Physiology and Pharmacology, 26, 5(2015), DOI:10.1515/jbcpp-2014-0105

6. C. A. Egedigwe, I. I. Ijeh, P. N. Okafor, and C. E. C. C. Ejike, Pharmaceutical Biology, 54, 12(2016), DOI:10.1080/13880209.2016.1216135

7. I. G. Sembiring, Repository USU (2013)

8. M. Lubis. Maulida, Repository USU, (2005).

9. A. A. Njan, B. Adzu, A. G. Agaba, D. Byarugaba, S. Díaz-Llera, and D. R. Bangsberg, Journal of Medicinal Food, 11, 3(2008), DOI:10.1089/jmf.2007.0511

10. D. A. Oyugi, X. Luo, K. S. Lee, B. Hill, and E. B. Izevbigie, Experimental Biology and Medicine, 234, 4(2009), DOI: 10.3181/0811-rm-325

11. M. Jisaka, H. Ohigashi, T. Takagaki, H. Nozaki, T. Tada, M. Hirota, R. Irie, M. A. Huffman, T. Nishida, M. Kaji, and K. Koshimizu, Tetrahedron, 48, 4(1992).

12. G. Igile, W. Olenszek, M. Jurzysta, R. Aquino, N. de Tommasi, and C. Pizza, Journal of Natural Products, 58, 9(1995), DOI:10.1021/np50123a016

13. A. L. Valverde, G. L. C. Cardoso, N. A. Pereira, A. J. R. Silva, and R. M. Kuster, Phytotherapy Research, 15, 3(2001), DOI:10.1002/ptr.733

14. A. M. Marzouk and O. B. Abd Elhalim, Natural Product Research, 30, 7(2015), DOI: $10.1080 / 14786419.2015 .1062004$

15. J. Wang, H. Song, X. Wu, S. Zhang, X. Gao, F. Li, X. Zhu, and Q. Chen, Molecules, 23, 3(2018), DOI:10.3390/molecules23030579

16. S. Patel, Biomedicine \& Pharmacotherapy, 84, 1(2016), DOI:10.1016/j.biopha.2016.10.030

17. A. P. Ambrosy, J. Butler, A. Ahmed, M. Vaduganathan, D. J. van Veldhuisen, W. S. Colucci, and M. Gheorghiade, Journal of the American College of Cardiology, 63, 18(2014), DOI:10.1016/j.jacc.2014.01.051

18. E. J. Eichhorn and M. Gheorghiade, Progress in Cardiovascular Diseases, 44, 4(2002), DOI: $10.1053 /$ pcad.2002.31591

19. M. Laursen, J. L. Gregersen, L. Yatime, P. Nissen, and N. U. Fedosova, Proceedings of the National Academy of Sciences, 112, 6(2015), DOI:10.1073/pnas.1422997112

20. R. Braga, V. Alves, M. Silva, E. Muratov, D. Fourches, A. Tropsha, and C. Andrade, Current Topics in Medicinal Chemistry, 14, 11(2014), DOI: 10.2174/1568026614666140506124442

21. A. Li, Toxicology, 104, 1(1995), DOI:10.1016/0300-483x(95)03155-9

22. C. A. Lipinski, Drug Discovery Today: Technologies, 1, 4(2004), DOI:10.1016/j.ddtec.2004.11.007

23. S. L. Fink, T. E. Robey, A. F. Tarabar, and M. E. Hodsdon, Clinical Toxicology, 52, 7(2014), DOI: $10.3109 / 15563650.2014 .932366$

[RJC-5638/2019] 